\title{
Toxicity of coke wastewater treated with advanced oxidation by Fenton process supported by ultrasonic field
}

\author{
Zmiana toksyczności ścieków koksowniczych poddanych \\ zaawansowanemu utlenianiu w układzie łączącym pole \\ ultradźwiękowe z odczynnikiem Fentona
}

\begin{abstract}
* Dr inż. Anna Kwarciak-Kozłowska, mgr inż. Aleksandra Krzywicka, Institute of Environmental Engineering, Department of Infrastructure and the Environment, Czestochowa University of Technology, Brzeznicka $60 A$ St., 42-200 Czestochowa, e-mail: akwarciak@is.pcz.czest.pl, aleksandra.krzyw@gmail.com
\end{abstract}

Keywords: coke wastewater, Fenton process, toxicity, ultrasonic field

Słowa kluczowe: ścieki koksowonicze, proces Fentona, toksyczność, pole ultradźwiękowe

\section{Abstract}

The aim of the presented study was to determine the toxicity of wastewater from the production of coke. The wastewater was treated with advanced oxidation involving ultrasonic field with Fenton's reagent (the amplitude was $61.5 \mu \mathrm{m}$ and sonication time $8 \mathrm{~min}$ ). Two doses of iron and four doses of hydrogen peroxide were used. The amount of hydrogen peroxide was proportional to the value of the chemical oxygen demand of raw wastewater, ranging from $\mathrm{COD} / \mathrm{H}_{2} \mathrm{O}_{2}$ ratio of 1:2.5 to 1:20. Two tests were used to determine the toxicity (algae growth inhibition test and Lepidium test).It was found that more toxic to algae was wastewater treated by Fenton's reagent containing a higher dose of iron. A similar inhibitory effect was observed on the germination of cress seeds.

๑) IOŚ-PIB

\section{INTRODUCTION}

Coke for metallurgy and heating is produced by distillation of coal at high temperatures to removing the volatile components. This process is accompanied by the formation of by-products and waste substances. The raw coke gases released during this process are collected and cooled. Coking gases contain water vapour, hydrocarbons and BTX (benzene, toluene and xylene). In subsequent gas purification, the by-products can be recycled from coke gas. The other compounds are condensed in water and the water is considered wastewater and needs to be treated at a wastewater treatment plant [Bernacki, 1957; Chang et al. 2008; Chmielniak 1986; Osantowski et al. 1981; Zhou et al. 2015]. Advanced oxidation processes are modern methods for wastewater treatment. This group of processes includes: Fenton reaction, $\mathrm{UV}$ (ultraviolet) $/ \mathrm{H}_{2} \mathrm{O}_{2}, \mathrm{UV}$ (ultraviolet) $/ \mathrm{O}_{3}$, photo-Fenton reaction and ultrasonic disintegration. The mechanism of reaction is based on generation of free hydroxyl radicals. These radicals are generated from hydroxyl peroxide with the participation of ferrous ions at acidic pH [Cao et al. 2009; Ghaly et al. 2001; Lloyd et al. 1997; Pera-Titus et al. 2004; Rubio-Clemente et al. 2015]. Hydroxyl radicals are characterised by high oxidation potential, which enables oxidation of most of the pollutants to water and carbon dioxide.

\section{Streszczenie}

Celem badań było określenie toksyczności ścieków powstających podczas koksowania węgla. Ścieki oczyszczano metodą zaawansowanego utleniania z odczynnikiem Fentona skojarzonej z polem ultradźwiękowym (wielkość amplitudy wynosiła 61,5 $\mu \mathrm{m}$ a czas nadźwiękawiania $8 \mathrm{~min}$ ). Zastosowano dwie dawki żelaza i cztery dawki nadtlenku wodoru. llość nadtlenku wodoru była proporcjonalna do wartości chemicznego zapotrzebowania na tlen surowych ścieków koksowniczych w zakresie od 1: 2,5 do 1: $20 \mathrm{ChZT}: \mathrm{H}_{2} \mathrm{O}_{2}$. Stwierdzono, że bardziej toksyczne dla glonów są ścieki poddane działaniu odczynnika odczynnika Fentona zawierającego mniejszą dawkę żelaza. Odmienne rezultaty zaobserwowano podczas oceny hamowania kiełkowania nasion rzeżuchy.
The ultrasonic field might also generate highly reactive hydroxyl radicals in aqueous solution from water molecules. Under appropriate condition, cavitation can initiate sonochemical reactions, including the formation of $\mathrm{OH}^{*}$ radicals. Created reactive radicals can break down the pollutants to simple compounds [Berlan et al. 1994; Chen and Huang 2011; Eren 2012; Gogate and Pandit 2004; Suslick 1989].

Advanced oxidation can contribute to the formation of the various compounds that may have toxic effects on organisms. Incomplete oxidation of recalcitrant could lead to the formation of toxic by-products. Hydroxyl radicals created in large quantities could also be toxic. There are many methods and indicators used for determining the toxicity of wastewater. A toxicity test can determine the relationship between the dose of toxic substance and the reaction of organisms. One of the toxicity indicators is $E C_{50}$, which determines the effective dose of toxic sample causing the effect in $50 \%$ of the tested population [Barbusiński 2005; Kaur and Dua 2015; Pignata et al. 2012; Winterbourn 1995].

The aim of the research was to determine the toxicity of treated wastewater. The level of toxicity was determined with algae growth inhibition test and Lepidium test. Coke processing 
wastewater samples were obtained after advanced oxidation with Fenton process supported with sonication.

\section{METHODS AND MATERIALS}

\subsection{Research material}

The $\mathrm{pH}$ of raw coke wastewater was 8.91. The wastewater was characterised by chemical oxygen demand (COD) $8287 \mathrm{mg} / \mathrm{dm}^{3}$ and biochemical oxygen demand $\left(\mathrm{BOD}_{5}\right)$ was $30 \mathrm{mg} / \mathrm{dm}^{3}$. The $\mathrm{BOD}_{5} / \mathrm{COD}$ ratio was at a low level -0.004 - that indicated low biodegradability. The amount of total organic carbon (TOC) was $2251 \mathrm{mg} / \mathrm{dm}^{3}$.

\subsection{Methodology}

This research was divided into two main stages. The first stage involved Fenton reaction, preceded by ultrasonic disintegration, and in the second stage, the toxicity of the samples was determined. The amplitude of ultrasonic field (UF) was $61.5 \mu \mathrm{m}$ and the disintegration time was established as 8 min [KwarciakKozłowska and Krzywicka, 2015]. Each sample was pre-treated by sonication before application of Fenton reaction. The doses of Fenton's reagent were different for each sample. Two doses of ferrous sulphate $\left(4 \mathrm{~g} / \mathrm{dm}^{3}\right.$ and $\left.40 \mathrm{~g} / \mathrm{dm}^{3}\right)$ and four doses of hydrogen peroxide were applied. The $\mathrm{H}_{2} \mathrm{O}_{2}$ dose was established by reference to the COD value of raw wastewater (COD: $\mathrm{H}_{2} \mathrm{O}_{2}$ $\mathrm{w} / \mathrm{w})$. The first dose was 1:2.5 and the others were double of the previous dose. Fenton reaction consisted of a few stages. First, the $\mathrm{pH}$ of raw wastewater was reduced to 3.0-3.5. After fast mixing of ferrous salt added to the reactor, hydrogen peroxide was added and the reaction lasted $60 \mathrm{~min}$. After this time, the mixture was neutralised. The last stage was sedimentation of the sludge, decantation and centrifugation. In the supernatant were determined the COD, $\mathrm{BOD}_{5}$, TOC and toxicity.

\subsection{Analyses}

The COD value was determined using the colorimetric method. OXITop $^{\circledR}$ (WTW GmbH) was used to determine the value of $\mathrm{BOD}_{5}$. TOC value was measured by Kiper TOC $10 \mathrm{C}$ analyser PX120 with autosampler. Algae growth inhibition test was used to

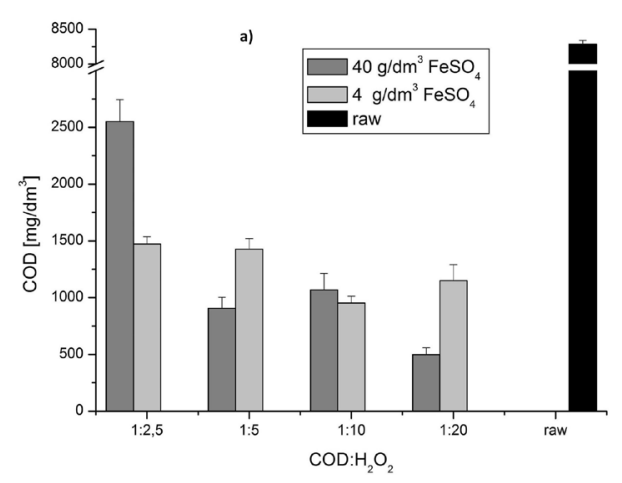

Fig. 1. COD (a) and TOC values (b) in treated wastewater. determine the $\mathrm{EC}_{50}$ value for toxicity [OECD 2011]. The phytotoxic effect was determined by the Lepidium sativum germination test [Janecka and Sobik-Szołtysek 2009].

\section{RESULTS}

In the first part of research, the COD value was determined. The research was divided into two series. In the first series, the dose of ferrous sulphate was $4 \mathrm{~g} / \mathrm{dm}^{3}$; it was 10 times higher in the second series. The COD value of raw wastewater was 8287 $\mathrm{mg} / \mathrm{dm}^{3}$. The reduction of COD was $84 \%$, on average, for both the series. The relationship between the amount of hydrogen peroxide and effectiveness on COD reduction was found for samples obtained after using higher dose of ferrous sulphate. Maximum reduction in the value of COD (94\%) was achieved for $\mathrm{COD} / \mathrm{H}_{2} \mathrm{O}_{2}$ ratio of $1: 20$ and it was $498 \mathrm{mg} / \mathrm{dm}^{3}$. For the first series, there was no clear difference in COD reduction $\left(4 \mathrm{~g} / \mathrm{dm}^{3}\right)$ depending on the dose of hydrogen peroxide. The COD removal was independent of the dose of hydrogen peroxide and was $85 \%$ on average. The highest dose of hydrogen peroxide (COD/ $\mathrm{H}_{2} \mathrm{O}_{2}$ ratio of $1: 20$ ) resulted in an increase of COD value. It was due to residual hydrogen peroxide (Fig.1a). The TOC value was $2251 \mathrm{mg} / \mathrm{dm}^{3}$ for raw wastewater. It was found that the $4 \mathrm{~g} / \mathrm{dm}^{3}$ of ferrous sulphate resulted in slightly lower TOC reduction than a higher dose. It was $75 \%$ on average, while TOC reduction was almost $10 \%$ higher after using 10 times higher dose of ferrous sulphate. For the second series of research, the relationship between the dose of hydrogen peroxide and TOC reduction was found. The higher the dose of hydrogen peroxide, the greater was the reduction of TOC. The maximum reduction was $97 \%$ and TOC value was $50 \mathrm{mg} / \mathrm{dm}^{3}$. It was observed that increasing the amount of hydrogen peroxide did not impress the TOC values found for lower dose of hydrogen peroxide (fig.1b).

The raw wastewater was characterised by $30 \mathrm{mg} / \mathrm{dm}^{3} \mathrm{BOD}_{5}$. The shape of the curve informs about the toxicity of wastewater to activated sludge microorganisms [Sadecka 2010]. In both the cases above, the shape of curves informs that samples of treated wastewater were low biodegradable. There was observed an inhibition of metabolic activity of microorganisms for the second series of research. The $\mathrm{BOD}_{5}$ value increased after adaptation of microorganisms for toxic substances presented in treated wastewater. The higher dose of ferrous sulphate resulted in

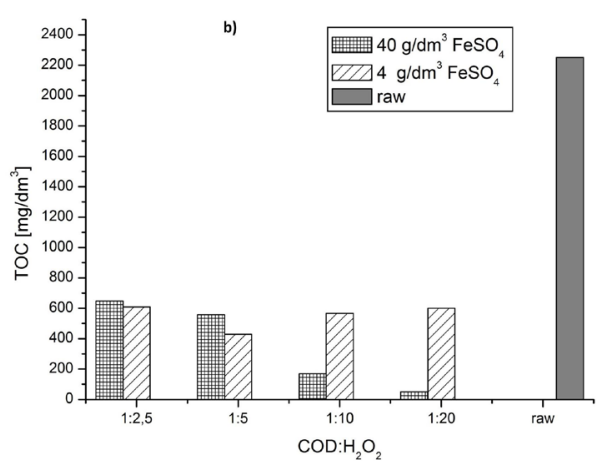



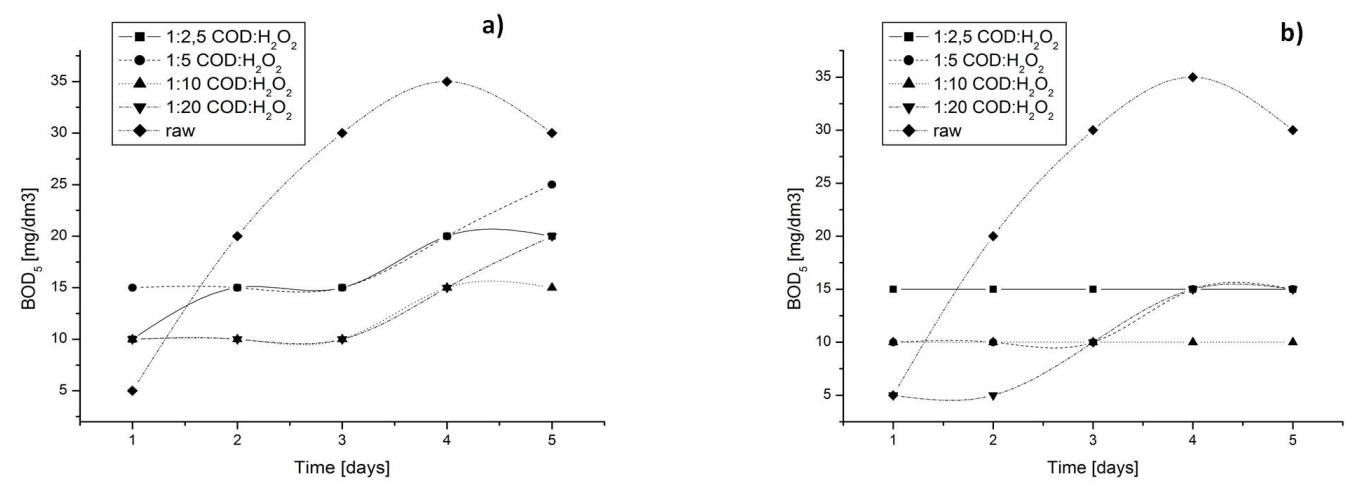

Fig. 2. The BOD values for lower (a) and higher (b) dose of ferrous sulphate in treated wastewater.
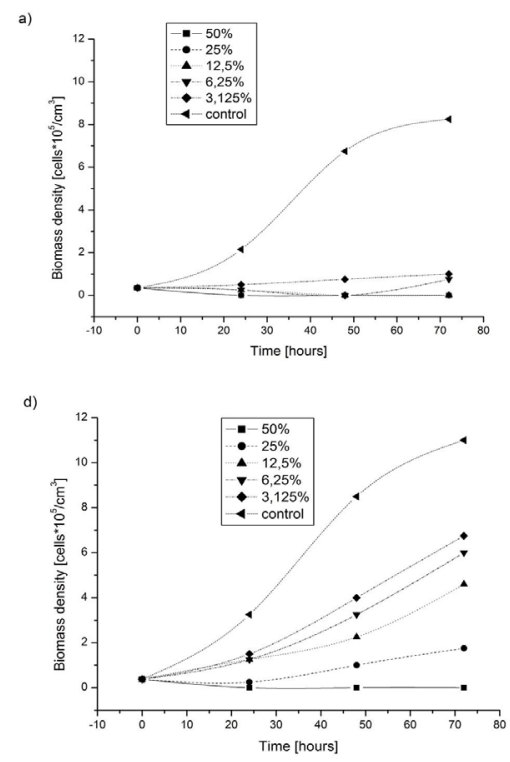

g)

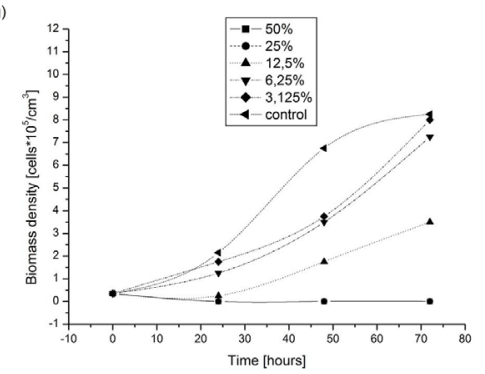

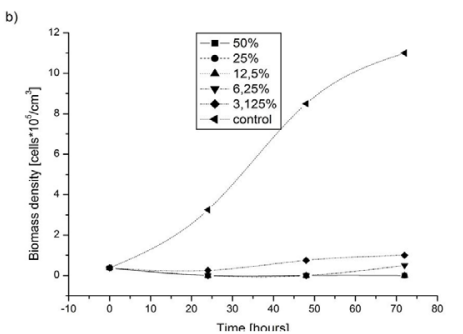

e)

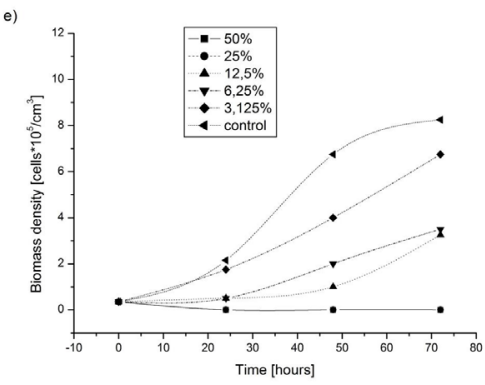

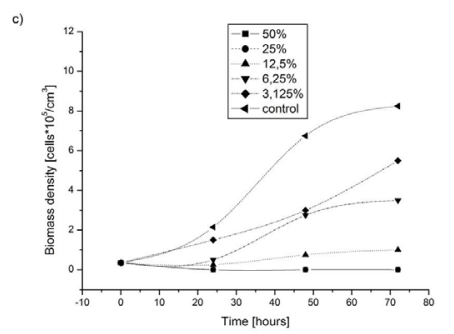

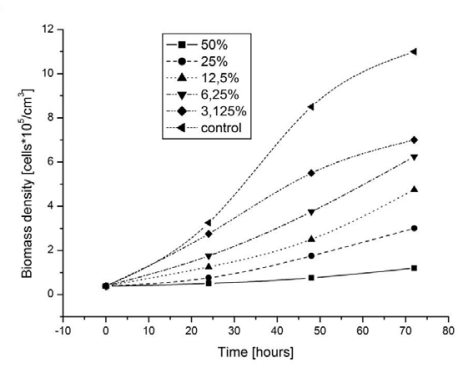

Fig. 3. Growth curve for $\mathrm{COD} / \mathrm{H}_{2} \mathrm{O}_{2}$ ratio of $1: 2.5(\mathrm{a}-\mathrm{b}), \mathrm{COD} / \mathrm{H}_{2} \mathrm{O}_{2}$ ratio of $1: 5(\mathrm{c}-\mathrm{d}), \mathrm{COD} / \mathrm{H}_{2} \mathrm{O}_{2}$ ratio of $1: 10(\mathrm{e}-\mathrm{f}), \mathrm{COD} / \mathrm{H}_{2} \mathrm{O}_{2}$ ratio of 1:20 (g-h).

low biodegradability of treated wastewater and higher toxicity of sample (fig.2). Similar results were observed in a previous research [Krzywicka, Kwarciak-Kozłowska 2015].

The main goal of this research was to determine the toxicity according to two tests. Algae cells were exposed for toxic effect of treated coke wastewater. The figures below present the growth curves for each dilution of wastewater sample. A typical growth curve has a lag, exponential (log phase), stationary and death phase. The last phase was not observed because of short time of growth. The growth curves were presented in the fig. $3 \mathrm{a}-\mathrm{h}$. The results obtained using lower doses of ferrous sulphate have been designated as a, c, e, g. Other graphs are for a 10 times higher dose of the reagent.

In every sample, a lag phase could be observed which is much about parallel to the OX axis. In this phase, algae adapt to the changed condition of the growth medium. The use of the lowest dose of hydrogen peroxide resulted in the lowest biomass growth. The lag phase was extended. It is believed that the algae needed a very long time to adapt to the presence of toxic substances. The shape of growth curves in fig. $3 a$ and $b$ are similar. It means that the 
Table 1. Toxicity of wastewater treated in UF-Fenton process for algae and Lepidium test.

\begin{tabular}{|c|c|c|c|c|c|c|c|c|c|}
\hline & & & & & Toxi & algae & & Toxi & for Lepidium \\
\hline & & & $1: 2.5$ & & 116 & Very high acute toxicity & & 33 & High acute toxicity \\
\hline & & & $1: 5$ & & 11 & High acute toxicity & & 4 & Acute toxicity \\
\hline & $\frac{E}{0}$ & & $1: 10$ & & 3 & Acute toxicity & & 4 & Acute toxicity \\
\hline & क) & & $1: 20$ & ؟ & 2 & Acute toxicity & $\subsetneq$ & 4 & Acute toxicity \\
\hline & & & $1: 2.5$ & E & 65 & High acute toxicity & $E$ & 116 & Very high acute toxicity \\
\hline$\frac{0}{5}$ & & & $1: 5$ & $\stackrel{\infty}{=}$ & 3 & Acute toxicity & $\stackrel{\infty}{=}$ & 5 & Acute toxicity \\
\hline $\bar{\omega}$ & है & $\mathrm{O}_{N}$ & $1: 10$ & $\sum_{\lambda}^{5}$ & 3 & Acute toxicity & & 7 & Acute toxicity \\
\hline L & চ্ডি & Оి & $1: 20$ & مُ & 3 & Acute toxicity & $\stackrel{\frac{1}{x}}{\circ}$ & 10 & Acute toxicity \\
\hline
\end{tabular}

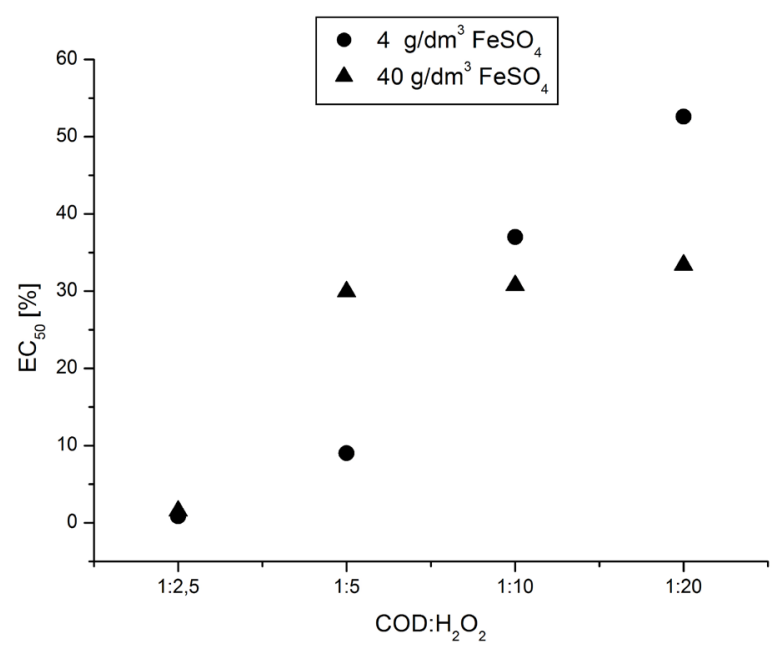

Fig. 4. The $\mathrm{EC}_{50}$ values for wastewater treated with Fenton reagent supported with ultrasonic field (UF).

toxic effect is due to the toxic substances from coke wastewater. The addition of hydrogen peroxide or ferrous sulphate did not cause toxic effect in this case. Exponential growth is the second phase, which is clearly shown in the fig. $3 d$ and $f$. The results show that the Fenton reagent containing a higher dose of ferrous sulfate contributed to better growth of algae biomass. Linear regression was used to calculate $\mathrm{EC}_{50}(0-72 \mathrm{~h})$. This indicator informs about the concentration of the medium, which leads to $50 \%$ inhibition of biomass growth. The results indicate that for the lower dose of ferrous sulphate $\left(4 \mathrm{~g} / \mathrm{dm}^{3}\right)$, toxicity changes are clearly visible. The more the dose of hydrogen peroxide used, the lower was the toxicity of sample. The $\mathrm{EC}_{50}$ was $53 \%$ for a COD/ $\mathrm{H}_{2} \mathrm{O}_{2}$ dose ratio of 1:20. A higher dose of ferrous sulphate $(40 \mathrm{~g} /$ $\mathrm{dm}^{3}$ ) resulted in wastewater characterised by a similar level of toxicity ( $31 \%$ on average) regardless of the amount of hydrogen peroxide in the Fenton reagent (fig.4).

The next stage of research was the Lepidium germination test. The seeds were cultivated in undiluted and diluted wastewater. The root elongation inhibition was calculated in test solutions. The results are shown in fig. 5a-d.

Rivera et al. [2013] suggested that high acute toxicity of nondiluted wastewater is connected with the turbidity of wastewater.
A high load of soluble and toxic substances in cultivation media can cause difficulties in the uptake of nutrients. The germination was inhibited mostly in the higher concentration of soluble and toxic substances in wastewater. The percentage of inhibition decreased with increase in dilution. Generally, higher root growth was observed for lower dose of ferrous sulphate $\left(4 \mathrm{~g} / \mathrm{dm}^{3}\right)$. This has not been dependent on the dilution of wastewater. A different relationship was observed for the lowest dose of hydrogen peroxide (fig. 5a). In this case, independent from the dilution of samples, the 10 times higher dose of ferrous sulphate resulted in lower inhibition of root elongation. The use of $4 \mathrm{~g} / \mathrm{dm}^{3}$ ferrous sulphate contributed to an increase in root elongation with increasing dose of hydrogen peroxide in non-diluted samples, except for the highest dose of hydrogen peroxide. The longest roots were obtained for $\mathrm{COD} / \mathrm{H}_{2} \mathrm{O}_{2}$ ratio of $1: 20$, and the inhibition of growth was $2.8 \%$ for the fifth dilution in comparison to the control. The last stage of research was to compare the toxicity of UF-Fenton treated wastewater in response to the two test organisms. The $\mathrm{EC}_{50}$ values were calculated into toxicity units (TU) according to [Persoone et al. 2003]. The results are shown in table 1 . The raw wastewater was characterised by very high acute toxicity to algae and Lepidium. The value of $\mathrm{EC}_{50}$ was under $1 \%$ for both the tests.

This system has classified most of the samples as acute toxic. Only the lowest dose of hydrogen peroxide in combination with the lower dose of ferrous sulphate has resulted in very high acute toxicity for algae or high acute toxicity for Lepidium. The lowest dose of hydrogen peroxide and 10 -fold higher dose of ferrous sulphate has resulted in reduction of toxicity by one class of toxicity for algae. The same relationship was observed for twice higher dose of hydrogen peroxide. The opposite results were observed for Lepidium test. In this case, deceasing the dose of ferrous sulphate has contributed to decreasing the toxicity of wastewater.

\section{CONCLUSION}

The combination of ultrasonic field and Fenton process has contributed to decrease in toxicity in comparison to the toxicity of raw wastewater. Generally, higher COD and TOC value reduction was obtained after application of a higher dose of ferrous sulphate $\left(40 \mathrm{~g} / \mathrm{dm}^{3}\right)$. The COD and TOC value decreased with increasing 
a)
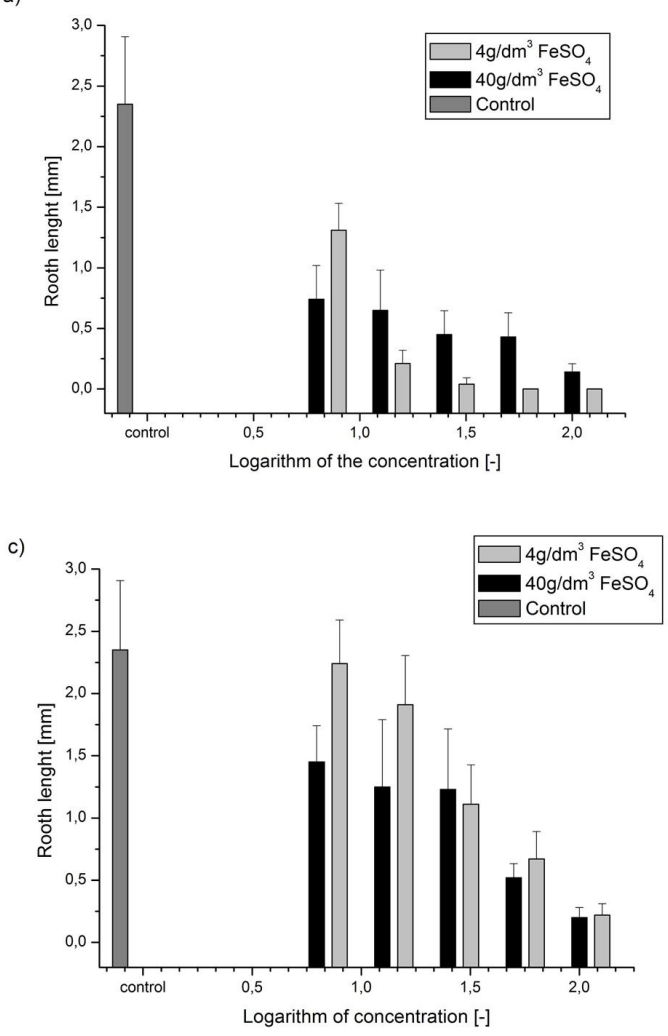
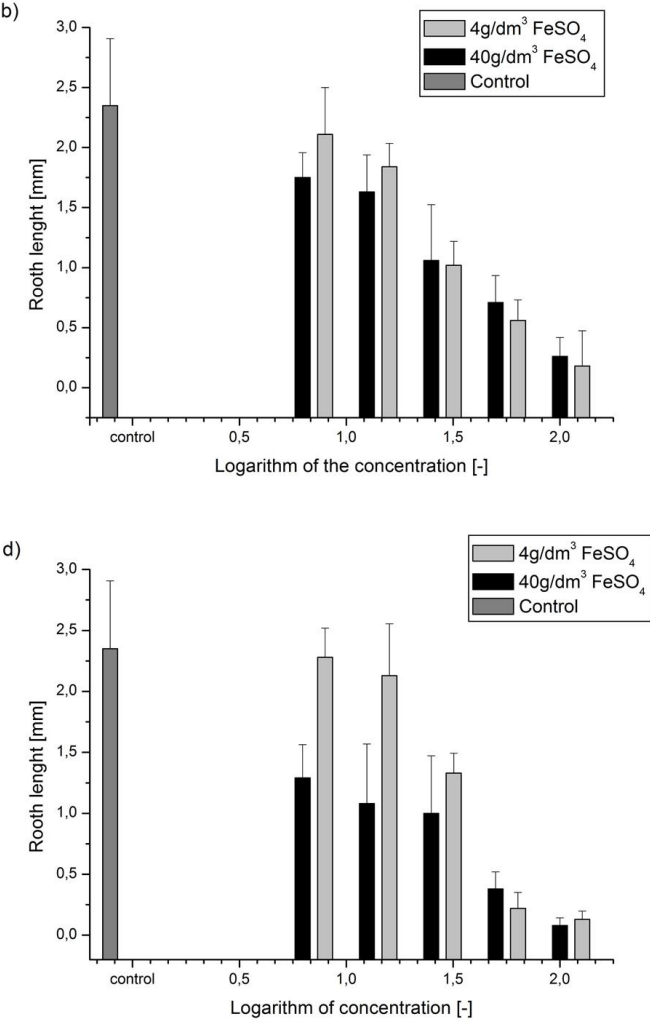

Fig. 5. Root length of Lepidium. a) $\mathrm{COD} / \mathrm{H}_{2} \mathrm{O}_{2}$ ratio of $1: 2.5$, b) $\mathrm{COD} / \mathrm{H}_{2} \mathrm{O}_{2}$ ratio of $1: 5$, c) $C O D / \mathrm{H}_{2} \mathrm{O}_{2}$ ratio of $1: 10$, d) $\mathrm{COD} / \mathrm{H}_{2} \mathrm{O}_{2}$ ratio of $1: 20$.

the dose of hydrogen peroxide in Fenton reagent. Lower biodegradability of wastewater was observed for the samples that were treated with Fenton reagent containing a higher dose of ferrous sulphate. Higher toxicity to Lepidium sativum was obtained when a higher dose of ferrous sulphate and the lowest dose of hydrogen peroxide were used. On the other side, higher toxicity to algae was observed for lower dose of ferrous sulphate. In this case, increasing the dose of hydrogen peroxide resulted in a decrease in toxicity.

\section{REFERENCES}

BARBUSIŃSKI K. 2005. Toxicity of Industrial Wastewater Treated by Fenton's Reagent. Polish Journal of Environmental Studies 14, 1: 11-16.

BERLAN J., TRABELSI F., DELMAS H., WILHELM A.M., PETRIGNANI J.F. 1994. Oxidative degradation of phenol in aqueous media using ultrasound. Ultrasonics Sonochemistry 1: $97-102$.

BERNACKI K. 1957. Ścieki fenolowe. Wydawnictwo Budowa i Architektura, Warszawa.

CAO G., SHENG M., NIU W., FEI Y., LI D. 2009. Regeneration and reuse of iron catalyst for Fenton-like reactions. Journal of Hazardous Materials 172: 1446-1449.

CHANG E.-E., HSING H.-J., CHIANG P.-C., CHEN M.-Y., SHYNG, J.-Y. 2008. The chemical and biological characteristics of coke-oven wastewater by ozonation. Journal of Hazardous Materials 156: 560-567.

\section{AKNOWLEDGMENTS}

This work was supported by BS/PB-401-301/11.

Aleksandra Krzywicka is a scholar of "DoktoRIS - the scholarship program for Innovative Silesia region" which is co-financed by European Social Found.

CHEN W.-S., HUANG Y.-L. 2011. Removal of dinitrotoluenes and trinitrotoluene from industrial wastewater by ultrasound enhanced with titanium dioxide. Ultrasonics Sonochemistry 18: $1232-1240$.

CHMIELNIAK K. 1986. Koksownictwo. Wydawnictwo Śląsk, Katowice.

EREN Z. 2012. Ultrasound as a basic and auxiliary process for dye remediation: A review. Journal of Environmental Management 104: 127-141.

GHALY M.Y., HÄRTEL G., MAYER R., HASENEDER R. 2001. Photochemical oxidation of $p$-chlorophenol by UV/H2O2 and photo-Fenton process. A comparative study. Waste Management 21: 41-47.

GOGATE P.R., PANDIT A.B 2004. Sonophotocatalytic reactors for wastewater treatment: A critical review. AIChE Journal 50: 1051-1079. 
JANECKAB., SOBIK-SZOŁTYSEKJ. 2009. Badania przydatności wybranych technik remediacji terenów zdegradowanych działalnością przemysłu cynkowo-ołowiowego. Inżynieria i Ochrona Środowiska 12, 4: 281-294.

KAUR R., DUA A. 2015. 96 h LC50, behavioural alterations and histopathological effects due to wastewater toxicity in a freshwater fish Channa punctatus. Environmental Science and Pollution Research 22: 5100-5110.

KRZYWICKA A., KWARCIAK-KOZŁOWSKA A. 2015. Wpływ reakcji foto-Fentona na toksyczność ścieków koksowniczych, in: Interdyscyplinarne zagadnienia w inżynierii i ochronie środowiska. Tom 5: 207-219. Oficyna Wydawnicza Politechniki Wrocławskiej.

KWARCIAK-KOZŁOWSKA A., KRZYWICKA A. 2015. Effect of ultrasonic field to increase the biodegradability of coke processing wastewater. Archives of Waste Management and Environmental Protection vol. 17, 3: 133-142.

LLOYD R.V., HANNA P.M., MASON R.P. 1997. The Origin of the Hydroxyl Radical Oxygen in the Fenton Reaction. Free Radical Biology and Medicine 22: 885-888.

OECD (Organization for Economic Co-operation and Development) 2011. Test No. 201: Freshwater Alga and Cyanobacteria, Growth Inhibition Test. Organisation for Economic Co-operation and Development, Paris.

OSANTOWSKI R., GEINOPOLOS A., ROLLINGER G. 1981. Physical/chemical treatment of coke plant wastewater. U.S. EPA, Research and Development, Industrial Environmental Research Laboratory, Research Triangle Park, NC 27211.

PERA-TITUS M., GARCÍA-MOLINA V., BAÑOS M.A., GIMÉNEZ J., ESPLUGAS S. 2004. Degradation of chlorophenols by means of advanced oxidation processes: a general review. Applied Catalysis B: Environmental 47: 219-256.
PERSOONE G., MARSALEK B., BLINOVA I., TÖRÖKNE A., ZARINA D., MANUSADZIANAS L., NALECZ-JAWECKI G., TOFAN L., STEPANOVA N., TOTHOVA L., KOLAR B. 2003. A practical and user-friendly toxicity classification system with microbiotests for natural waters and wastewaters. Environ. Toxicol. 18: 395-402.

PIGNATA C., FEA E., ROVERE R., DEGAN R., LORENZI E., DE CEGLIA M., SCHILIRO T., GILLI G., 2012. Chlorination in a wastewater treatment plant: acute toxicity effects of the effluent and of the recipient water body. Environmental Monitoring and Assessment 184: 2091-2103.

RIVERA E.B., MILLA O.V., HUANG W.-J., HO Y.-S., CHIU J.-Y., CHANG H.-Y. 2013. Rice Germination as a Bioassay to Test the Phytotoxicity of MSWI Bottom Ash Recycling Wastewater. Journal of Hazardous, Toxic, and Radioactive Waste 17: 140 145.

RUBiO-Clemente A., ChICA E., PENUELA G.A. 2015. Petrochemical Wastewater Treatment by Photo-Fenton Process. Water, Air, \& Soil Pollution 226, 3: 1-18.

SADECKA Z. 2010. Podstawy biologicznego oczyszczania ścieków. Seidel-Przywecki Sp. z o.o.

SUSLICK K.S. 1989. The chemical effects of ultrasound. Scientific American 2: 80-86.

WINTERBOURN C.C., 1995. Toxicity of iron and hydrogen peroxide: the Fenton reaction. Toxicology Letters, Proceedings of the International Congress of Toxicology - VII, 82-83: 969974.

ZHOU S., WATANABE H., WEI C., WANG D., ZHOU J., TATARAZAKO N., MASUNAGA S., ZHANG Y. 2015. Reduction in toxicity of coking wastewater to aquatic organisms by vertical tubular biological reactor. Ecotoxicology and Environmental Safety 115: 217-222. 